UDK 629.113

DOI: 10.30977/AT.2219-8342.2021.48.0.27

\title{
FEATURES OF ADAPTIVE BRAKE CONTROL OF THE SECONDARY BRAKE SYSTEM OF A MULTI-AXLE VEHICLE
}

\author{
Bogomolov V. O. ${ }^{1}$, Klimenko V. I. ${ }^{1}$, Leontiev D. M. ${ }^{1}$, \\ Kuripka O. V. ${ }^{1}$, Frolov A. A. ${ }^{1}$, Don E. Yu. ${ }^{1}$ \\ ${ }^{1}$ Kharkiv National Automobile and Highway University
}

\begin{abstract}
Problem. Malfunction of the service braking system of a wheeled vehicle (WV) significantly affects road safety, especially when operating multi-axle vehicles with big masses. One of the ways to increase the level of road safety of multi-axle vehicles, when braking using a spare (emergency) braking system, is the introduction of automated adaptive braking systems into the design of the brake drive of vehicles. The definition of the limits of using the adaptive braking system on vehicles with many axles is almost not disclosed in the scientific and technical literature, therefore, the issue of using such a system on vehicles with a large number of axles requires additional research. Purpose. The purpose of this work is to develop a simulation model for adaptive control of the braking process of a multi-axle vehicle using a spare (emergency) braking system, taking into account the simulation of the dynamics of the drive and the variability of the adhesion properties between the tire of the vehicle wheel and the road surface. Methodology. To achieve this goal, it is necessary to develop a simulation model of the brake drive in an adaptive mode, implement a model of the interaction of the tire with the road surface, and implement a model of the braking dynamics of a multi-axle vehicle in the event of a malfunction of its service brake system. Originality. The proposed key criterion $\left(K_{r}\right)$ for changing the throttle section in electro-pneumatic pressure modulators, which provide adaptive air inlet or outlet from the corresponding brake chambers of the drive, during simulation, made it possible to simulate the operation of the drive circuits in the adaptive mode. It has been established that, depending on the potential for the realization of the adhesion between the tires of automobile wheels and the road surface, the pressure in the electro-pneumatic brake drive with its adaptive regulation can be increased by no more than $0.04 \mathrm{MPa}$.
\end{abstract}

Keywords: brake control, multi-axle vehicle, adaptive control, braking, secondary brake system, emergency braking, adhesion utilized by axle.

\section{Introduction}

Failure of the working brake system of a wheeled vehicle (WV) significantly affects road safety, especially during operation of multi-axle vehicles with large masses. One of the ways to increase the level of road safety of multi-axle vehicles, during their braking using a secondary (emergency) braking system, is the introduction into the design of the brake drive WV automated adaptive braking systems. Determining the limits of the use of adaptive braking system on vehicles with many axles in the scientific and technical literature is almost not disclosed, so the question of using such a system on WV with a large number of axles requires further research.

\section{Analysis of publications}

A search analysis on the Internet showed that a number of scientific papers have been devoted to the use of an adaptive brake system on the WV [1-6]. Based on these studies, it is established that determining the braking efficiency of multi-axle vehicles is a difficult task, because the brake system of multi-axle WV is divided into several independent circuits [7-12], which can work differently due to the implementation of adaptive control algorithms for pneumatic brake actuators. The analysis of scientific works [13-14] showed that most authors consider the issue of adaptive braking in terms of the implementation of permanent coupling properties between the tire of the vehicle wheel and the road surface. At the same time, in scientific works [15-17] it is noted that the adhesion properties between the tire and the road surface are constantly changing depending on a combination of different factors, such as: changes in wheel load, tire slip speed relative to the road surface [ 13-16], the condition of the road surface and more. Therefore, when studying the issue of adaptive braking of vehicles in addition to choosing the method of forming the amount of braking torque in modeling the dynamic properties of the interaction of the vehicle wheel with the road surface [18-15] should take into account changes in the adhesion properties of vehicle wheels with the road surface [24-27]. 


\section{Purpose and problem statement}

The purpose of this work is to develop a simulation model of adaptive control of multiaxle vehicle braking using a secondary (emergency) braking system, taking into account the simulations of drive dynamics and variability of adhesion properties between the tire of the vehicle wheel and the road surface.

To achieve this goal it is necessary to develop a simulation model of the brake drive in adaptive mode, to implement a model of interaction of the tire with the road surface, to implement a model of braking dynamics of a multiaxle vehicle in case of failure of its service brake system.

\section{Main research}

Analysis of scientific and technical literature [27] showed that the magnitude of the braking torque can be determined from the dependence [27]:

- for drum brake mechanism:

$$
M_{T i}=F_{a} \cdot i_{S} \cdot \eta \cdot K_{e} \cdot r_{t b} \cdot p_{i},
$$

where $F_{a}$ - active area of the brake chamber or pneumatic cylinder, $\mathrm{m}^{2}$;

$i_{S}$ - gear ratio of the mechanism of unclamping of brake pads;

$\eta$ - efficiency of the brake mechanism;

$K_{e}$ - coefficient of the drum brake mechanism;

$p_{i}$ - the pressure in the brake chamber of the corresponding circuit of the brake actuator, $\mathrm{Pa}$;

- for the disc brake mechanism:

$$
M_{T i}=F_{a} \cdot i_{T} \cdot \eta \cdot n_{d} \cdot K_{e}^{T} \cdot \rho_{H} \cdot p_{i},
$$

where $i_{T}$ - gear ratio of the disc brake mechanism;

$n_{d}-$ the number of friction pairs in the disc brake;

$K_{e}^{T}-$ coefficient of the disc brake mechanism;

$\rho_{H}-$ the average radius of friction of the brake pad on the disc.

The realized force in the patch of contact of the tire with the support surface is determined by the formula [23]:

$$
R_{x}=\frac{C_{x} \cdot \xi_{x}}{r_{d}},
$$

where $C_{x}-$ the tangential stiffness of the tire, $\mathrm{N} \cdot \mathrm{m} / \mathrm{rad}$;

$\xi_{x}$ - angular displacement, rad;

wheel, $\mathrm{m}$.

$r_{d}$ - dynamic radius of the vehicle

\section{Mathematical model of secondary brake system control}

Assume that the control of the secondary brake system is possible on the basis of matching the value of the adhesion realized obtained from the equation of torques of the vehicle wheel relative to its axis (4) and the value of the adhesion realized force obtained from equation (3).

Thus, the adhesion realized will be the main criterion for adapting the operation of the service brake system in case of failure of any elements of its brake actuator. Therefore, the value of the adhesion realized is determined from the dependence:

$$
f_{i}=\frac{M_{T i}+R_{f_{R}} \cdot r_{d}-M_{j i}}{r_{d} \cdot R_{z i}},
$$

where $M_{T i}$ - the braking moment, $\mathrm{N} \cdot \mathrm{m}$;

$M_{j i}$ - inertial moment of the wheel, $\mathrm{N} \cdot \mathrm{m}$;

$R_{z i}$ - the vertical load on the axle, $\mathrm{N}$;

$R_{f_{R}}$ - the rolling resistance force of a vehicle wheel, $\mathrm{N}$.

The inertial moment of the vehicle wheel is determined from the known dependence:

$$
M_{j i}=-I_{k} \frac{d \omega}{d t},
$$

where $I_{k}$ - the moment of inertia of the wheel, $\mathrm{kg} \cdot \mathrm{m}^{2}$;

$\mathrm{c}^{-2}$

$$
\frac{d \omega}{d t}-\text { angular deceleration of the wheel, }
$$

For vehicle wheels with a static radius from $0.4 \mathrm{~m}$ to $0.575 \mathrm{~m}$, the moment of inertia can be determined with sufficient accuracy depending on

$$
I_{k}=92-473 \cdot r_{s t}+636 \cdot r_{s t}^{2},
$$


where $r_{s t}=r_{d}$-static wheel radius, $\mathrm{m}$.

Based on the mathematical model, we use the dependence (7) to determine the amount of deceleration of a four-axle wheeled vehicle, which is based on the adhesion realized of the tires of vehicle wheels and the coordinates of the center of gravity vehicle:

$$
j_{a}=g \cdot \frac{\sum_{i=1}^{2} A \cdot b_{g}+\sum_{i=3}^{4} A \cdot a_{g}}{1-h_{g}\left(\sum_{i=1}^{2} A-\sum_{i=3}^{4} A\right)},
$$

where $a_{g}, b_{g}$ and $h_{g}$ - longitudinal and vertical coordinates of the location of the center of gravity of a four-axle wheeled vehicle, $\mathrm{m}$;

$$
\sum_{i=1}^{2} A \text { and } \sum_{i=3}^{4} A \text { - parameters that are de- }
$$

termined by dependencies:

$$
\begin{aligned}
& \sum_{i=1}^{2} A=\sum_{i=1}^{2} \frac{f_{i}}{\lambda_{i}\left(a_{g}+b_{g}+x_{i}\right)} \\
& \sum_{i=3}^{4} A=\sum_{i=3}^{4} \frac{f_{i}}{\lambda_{i}\left(a_{g}+b_{g}+x_{i}\right)},
\end{aligned}
$$

where $x_{i}$ - the corresponding longitudinal coordinates of the location of the axles of the wheeled vehicle relative to the center of gravity, $\mathrm{m}$.

When modeling the brake actuator in the adaptive mode, we use as a criterion $\left(K_{r}\right)$ changes in the cross-sections of the chokes in electropneumatic pressure modulators, on the adaptive inlet or outlet, the ratio of the current value of the adhesion realized force obtained from equation (4) to the limit value of the adhesion force, which can be determined from equation (3):

$$
K_{r}=\frac{M_{T}+R_{f_{R}} \cdot r_{d}-M_{j}}{C_{\xi} \cdot \xi_{x}^{\max }},
$$

Criterion $\left(K_{r}\right)$ determines, in addition to the value of the cross-section in the pressure modulator, also the initial conditions (pressure at the inlet to the modulator or the pressure of the medium where the air is released) when determining the flow of compressed air in the electropneumatic pressure modulator.

\section{Simulation model of secondary brake system control}

The simulation model of the control system of the secondary braking system, which has adaptive properties, is an integral part of the simulation model of the braking of a wheeled vehicle.

For example, for a four-axle wheeled vehicle, the simulation model of the braking dynamics of the vehicle can be presented in the form of a block diagram (Fig. 1) built in the Simulink package MatLAB environment. The block diagram of the simulation model of the secondary brake system will have the form shown in Figure 2. Each of the elements in the block diagrams (Fig. 1 and Fig. 2) is a structurally logical connections that work in a closed cycles during the implementation of 30,000 iterations of the calculation in the time interval from $0 \mathrm{~s}$ to $3.5 \mathrm{~s}$.

The block diagram shown in Figure 1 consists of:

1. The unit that determines the nature of the pressure change in the first, second and third circuits of the brake actuator;

2. The block of definition of the adhesion realized between tires of vehicle wheels and a road surface;

3. The unit for determining the braking rate of the vehicle;

4. The unit for determining the change in speed of the vehicle during its deceleration;

5. The block of redistribution of vertical loading between the corresponding axes of the four-axle vehicle.

The block diagram shown in Figure 2 clearly shows that on the basis of the criterion $\left(K_{r}\right)$ is the formation of a signal in the pressure modulator on the intake or exhaust air in the electropneumatic pressure modulator. The criterion $\left(K_{r}\right)$ also determines the initial conditions in the simulation model of the electropneumatic brake actuator.

The results of simulation modeling of the braking process of a four-axle vehicle with an electropneumatic brake drive, which can operate in adaptive mode, are presented graphically in Figures 3 - 9.

For convenience of the analysis of schemes of a brake drive of the vehicle we will designate them by coding of the following look:

$$
I-I I-I I I
$$

where $I, I I$ and $I I I$ - respectively, the number of the brake circuit. 


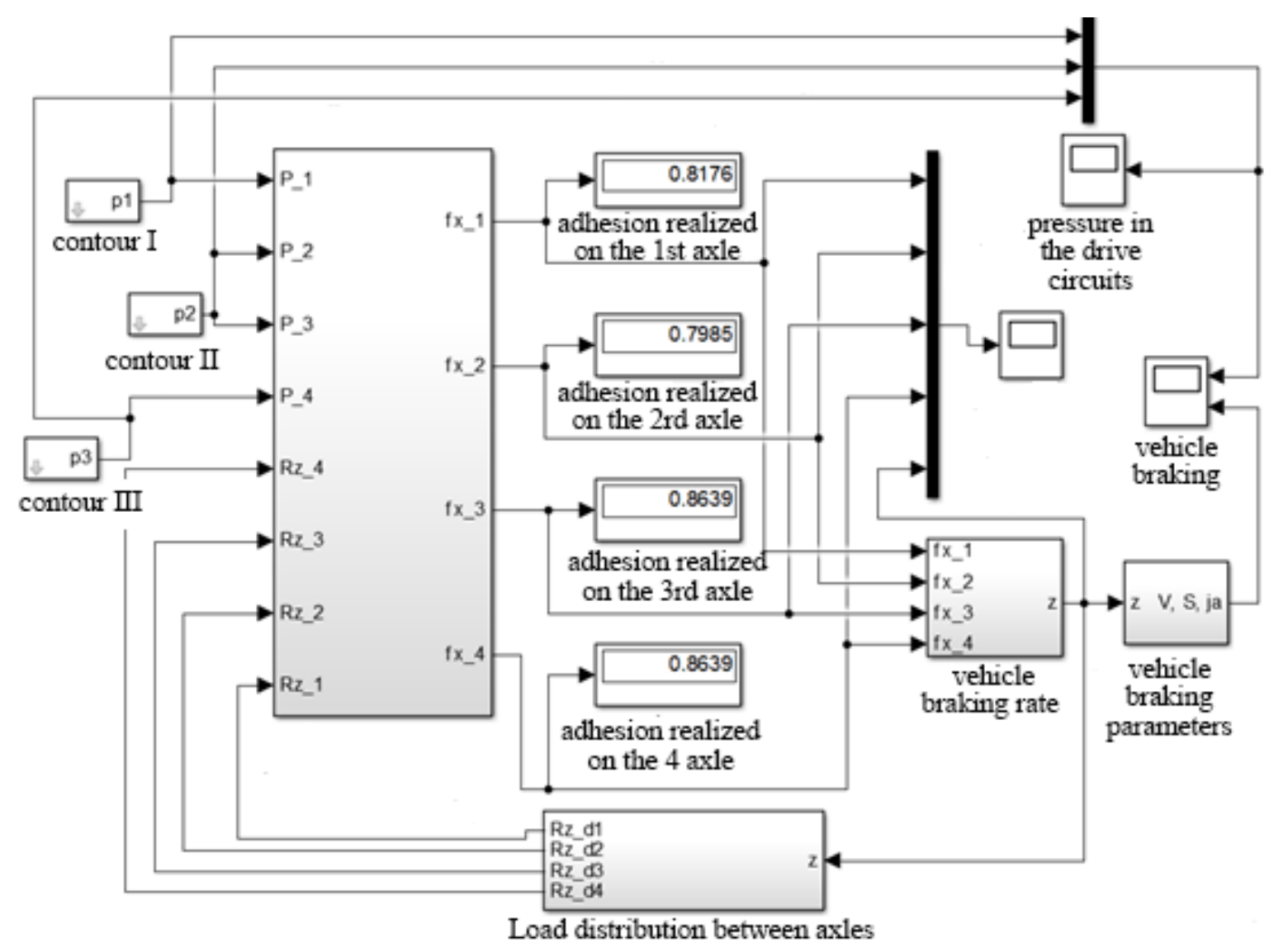

Fig. 1. Block diagram of a simulation model of the braking dynamics of a four-axle vehicle

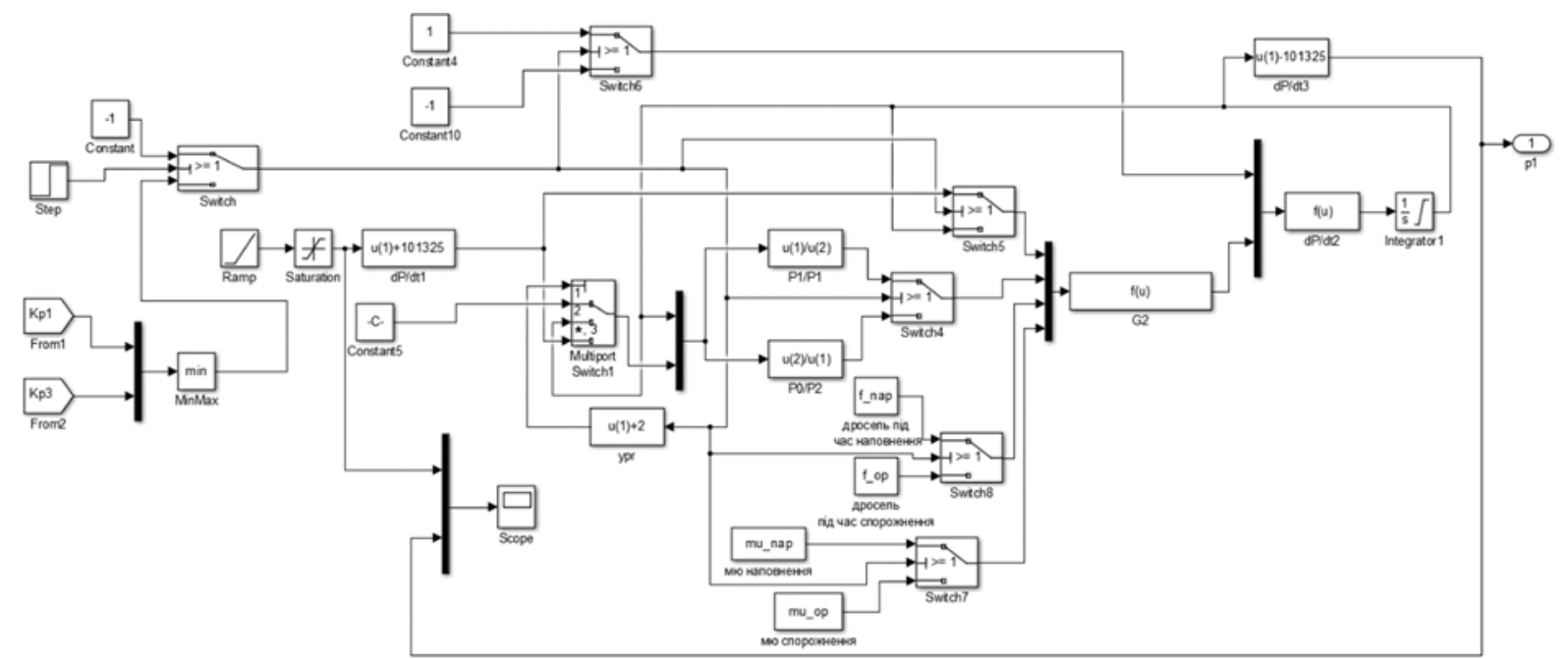

Fig. 2. Block diagram of the simulation model of control of the secondary brake system

Each brake circuit can have several connection points to the brake mechanisms of the axles of a multi-axle vehicle, so marked the connection points of the respective circuits through the letters written as a fraction, for example:

$$
A / B-C-D \text {. }
$$

This entry for a four-axle vehicle with brake mechanisms of "simplex" type will indicate that two brake mechanisms, the first and second axles of the vehicle, are connected to the first brake actuator circuit. The third axis of the vehicle is connected to the second circuit and the fourth axis of the vehicle is connected to the third circuit.

An example of the result of simulation modeling of pressure change in the I, II, II and III circuits of the electropneumatic brake actuator during their sequential failure (I circuit failed at 
time $1 \mathrm{~s}$, II - in time time $2 \mathrm{~s}$, and III at time $3 \mathrm{~s}$ ) are shown in Figures 3 and 4. The simulation results are shown in Figure 3 and Figure 4 are performed for a vehicle with a circuit connection circuit $I-I I-I I I \rightarrow A / B-C-D$ to brake mechanisms of the "simplex" type with a single splinting of the vehicle wheels.
From the example (Fig. 3) it can be seen that the increase in pressure in the II and III circuit of the brake actuator in the event of failure of the I circuit occurs in proportion to the decrease in the amount of adhesion between the tires of the respective wheels of the vehicle and the road surface (Fig. 4).

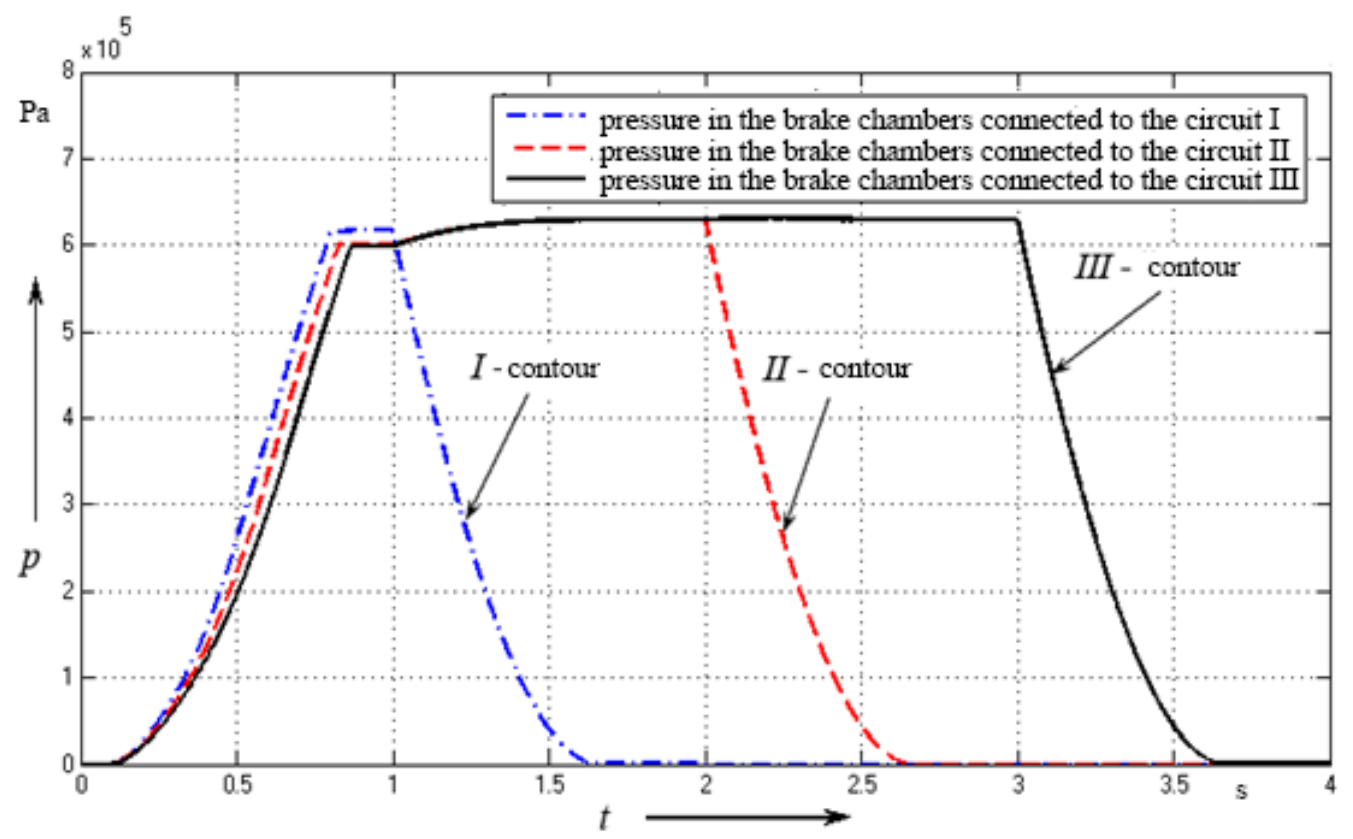

Fig. 3. The result of simulation modeling of the pressure change in the electropneumatic brake actuator taking into account the adaptive properties of the brake system of the vehicle (scheme of designation $A / B-C-D$ )

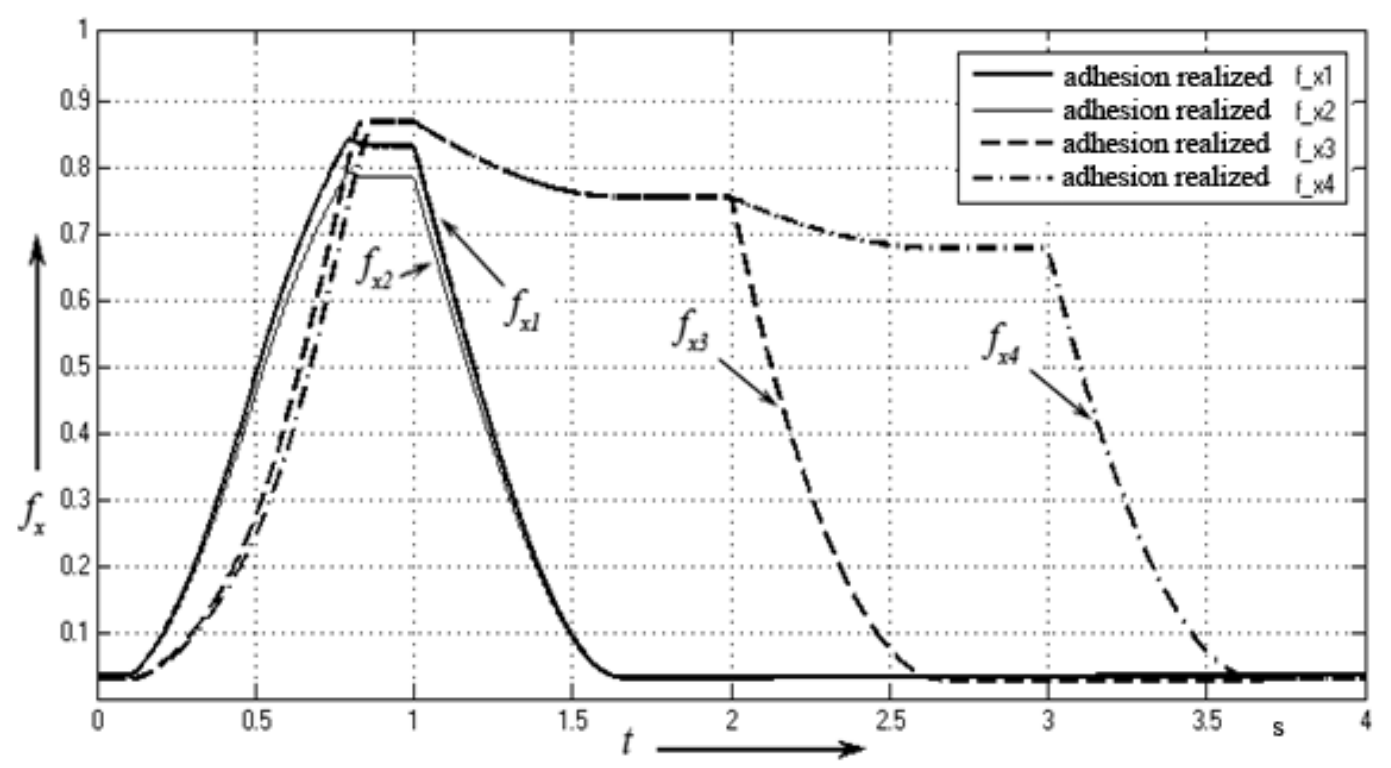

Fig. 4. Simulation modeling of the change of the realized coupling between the tires of the respective wheels of the vehicle axles and the road surface (the scheme of designation $A / B-C-D$ )

The fall of the adhesion realized between the tires of automobile wheels and the road surface on the third and fourth axles of the wheeled vehicle, in the time range from $1 \mathrm{~s}$ to $2 \mathrm{~s}$, is ex- plained by the increase of vertical load on these axles at failure of the first brake circuit.

The fall of the adhesion realized on the fourth axle of the vehicle (Fig. 4), in the time range from $2 \mathrm{~s}$ to $3 \mathrm{~s}$ is also associated with an 
increase in axle load and an additional decrease in vehicle deceleration due to failure of the 2 nd circuit of the brake actuator after $2 \mathrm{~s}$ (Fig. 3).

The correspondence of the adhesion realized $\left(f_{x 3}\right)$ to the adhesion realized $\left(f_{x 4}\right)$ during the simulation time from $1 \mathrm{~s}$ to $2 \mathrm{~s}$ (Fig. 4) is explained by the fact that the third and fourth axles of the modeled vehicle are connected by a balancing trolley, which extends axles 3 and 4 of a four-axle wheeled vehicle. The performed calculations for another layout scheme of connection of the brakes of the brake drive $(I-I I-I I I \rightarrow A-B$ $C / D$ ) with brake mechanisms of the "simplex" type with a single busbaring of all wheels of a four-axle wheeled vehicle show (Fig. 5 and Fig. 6 ) that it will not be possible to make a significant increase in pressure in the electropneumatic brake actuator during the adaptive control of the secendary brake system.

Based on simulation studies, it was found that the maximum value by which the pressure in the serviceable circuits of an electropneumatic brake actuator with adaptive properties can be increased is not more than $0.04 \mathrm{MPa}$ when the adhesion realized changes to two tenths of a unit (Fig. 6).

It should also be noted that increasing the value of the adhesion realized, while performing the adaptive functions of the brake system of a wheeled vehicle, cause to reduce the pressure in the brake drive and vice versa, while reducing the adhesion realized allows to increase the pressure in the circuit.

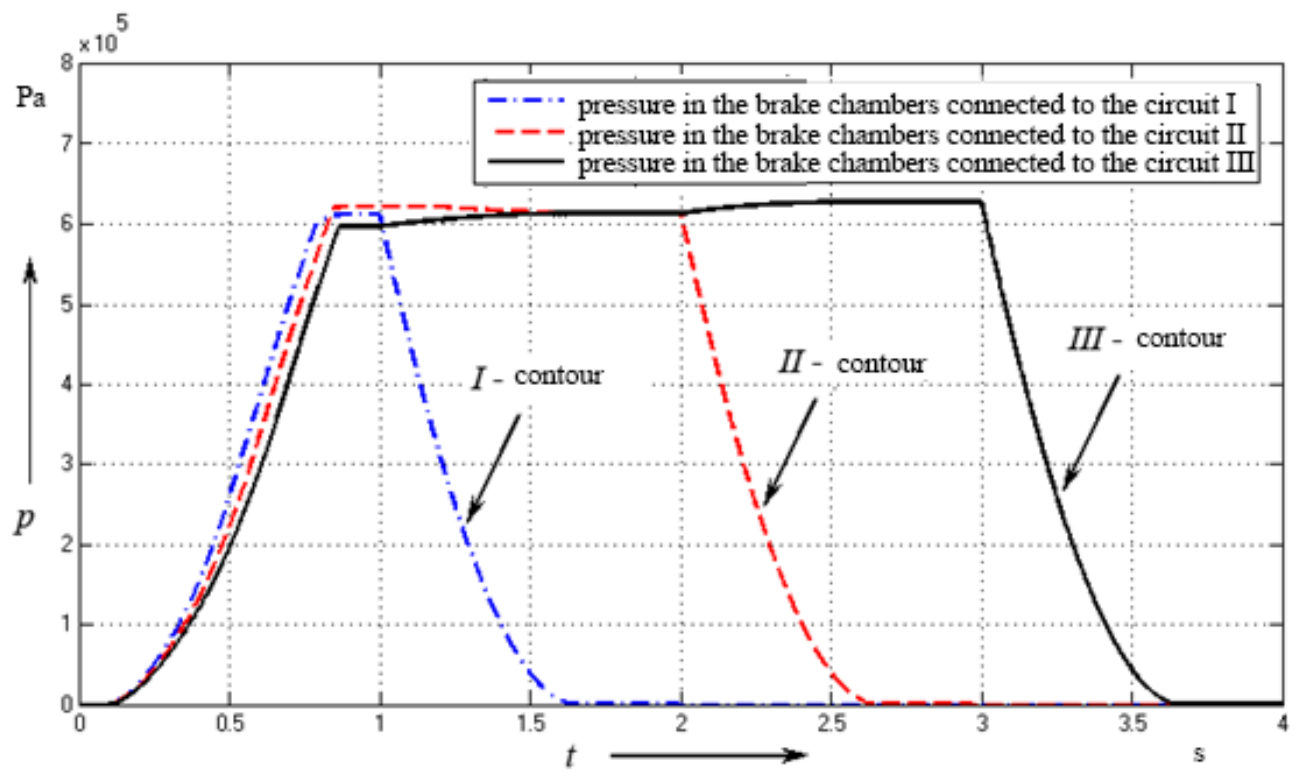

Fig. 5. The result of simulation modeling of the pressure change in the electropneumatic brake actuator taking into account the adaptive properties of the brake system of the vehicle (scheme of designation $A-B-C / D$ )

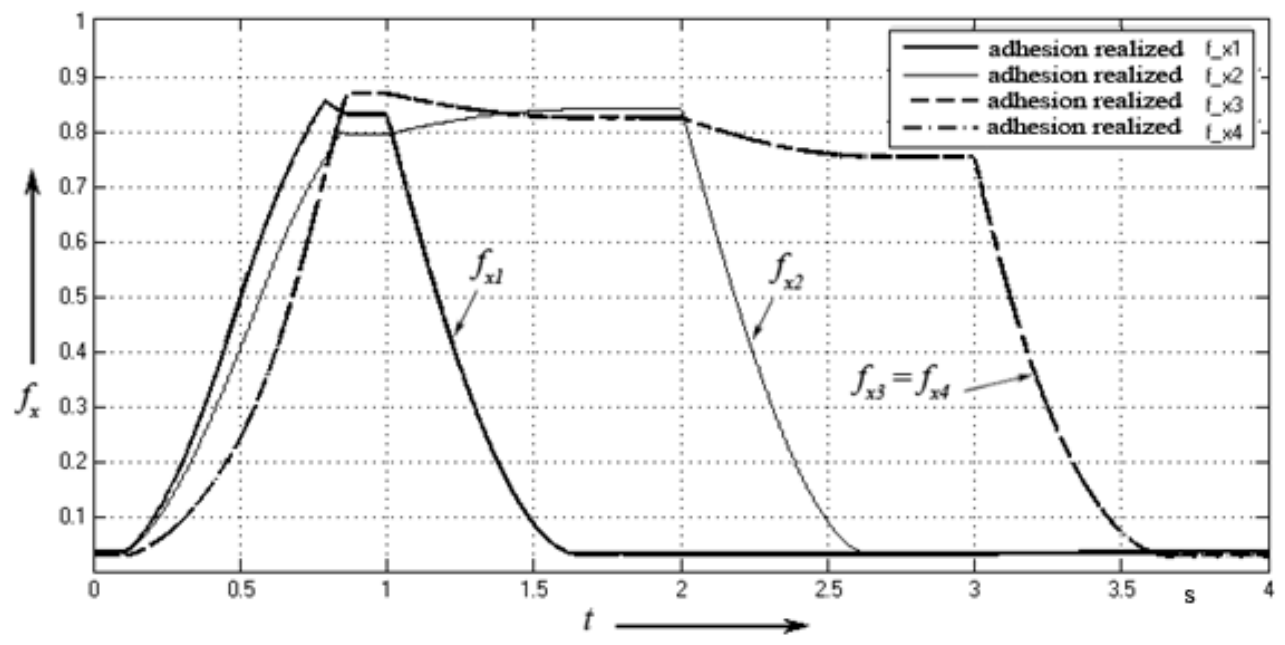


Fig. 6. Simulation modeling of the change of the adhesion realized between the tires of the respective wheels of the vehicle (scheme of designation $A-B-C / D$ )

This is due to the rolling of the car wheel on the verge of locking it with a deceleration that provides no more than $20 \%$ of the car tire sliding relative to the road surface.

Studies of braking of a wheeled vehicle (Fig. 9) in cases where the driver limits the pressure in front of the modulator showed that when the driver limits the pressure in the brake drive at a level of, for example, $0.4 \mathrm{MPa}$ (Fig. 7), and provided not exceeding the locking limits of automobile wheels (Fig. 8), the possibility of increasing the pressure in the drive is absent for the realization of the adaptive properties of the brake system, since there is no excess pressure in the electropneumatic brake drive necessary for the regulation of brake forces.

Therefore, it should be noted that during service braking, it is necessary to ensure the implementation of the tracking action of the brake system due to the proportionality between depressing the brake pedal and deceleration of the vehicle, rather than taking into account the proportional increase in pressure in the drive circuit.

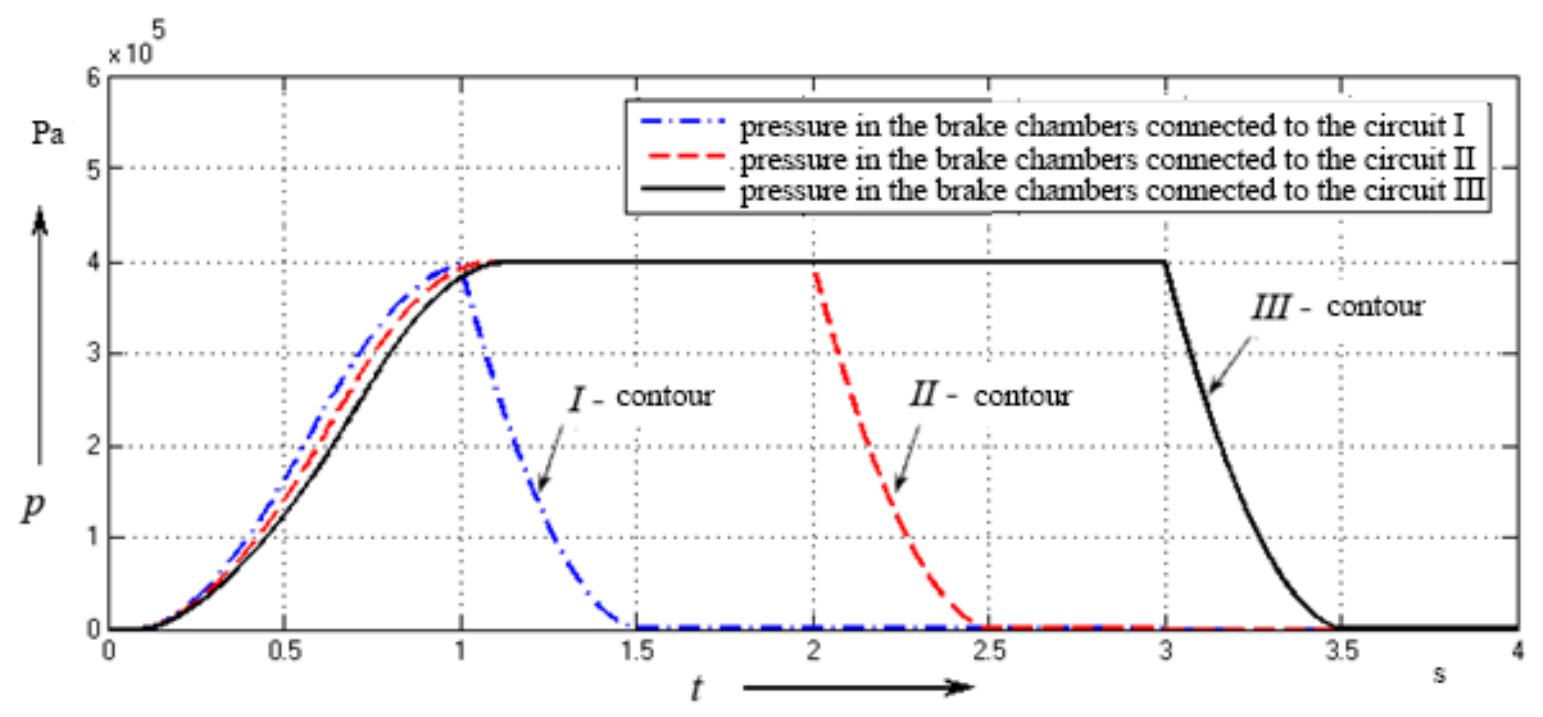

Fig. 7. The result of simulation modeling of the pressure change in the electropneumatic brake actuator during service braking of the vehicle (any scheme of connection of the brake actuator to the brake mechanisms mounted on the axles of the vehicle)

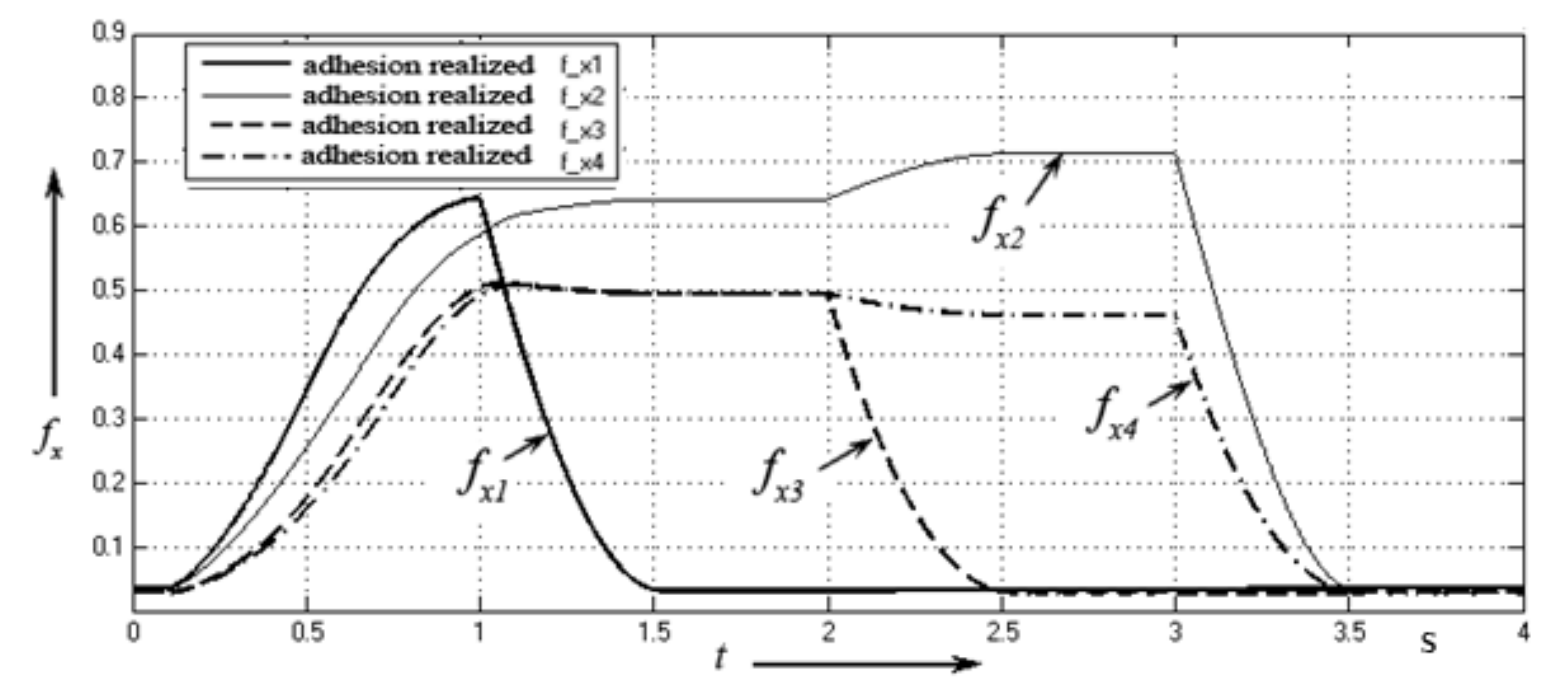

Fig. 8. Simulation modeling of the change of the adhesion realized between the tires of the corresponding wheels of the vehicle during its service braking (scheme of designation $A-C-B / D$ ) 


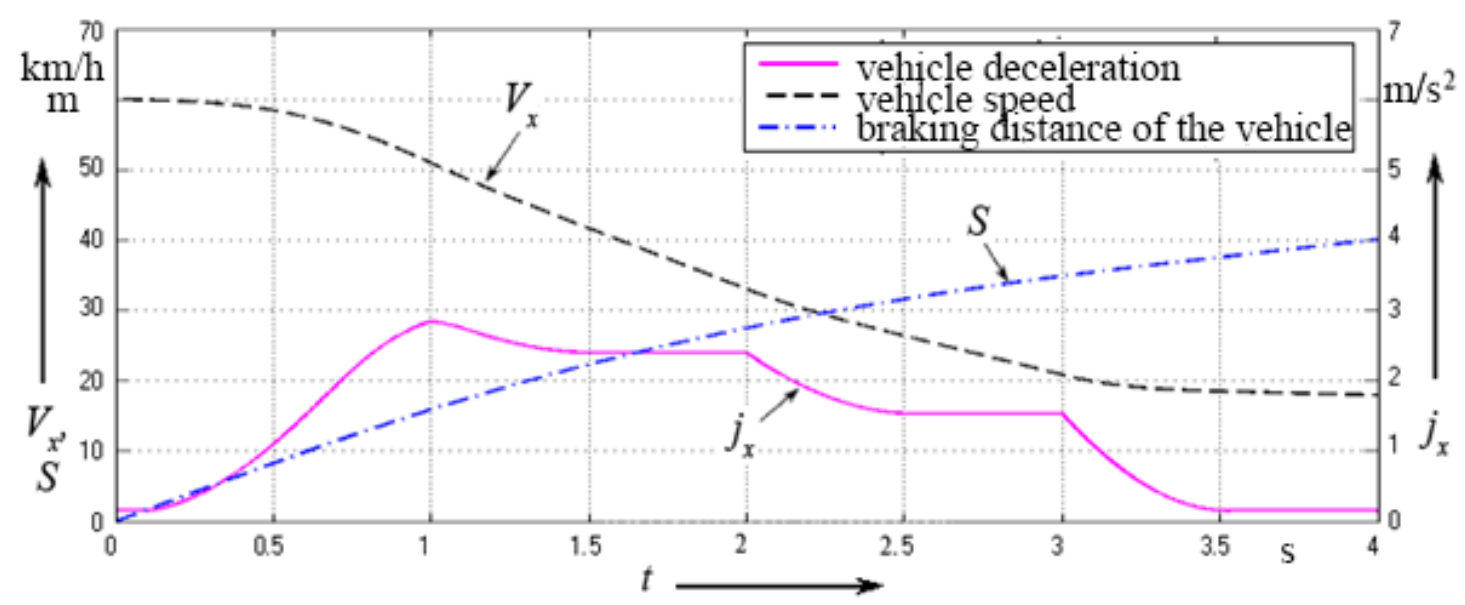

Fig. 9. Simulation modeling of change of initial parameters of a vehicle during its service braking (the scheme of designation $A-C-B / D$ )

It is obvious that in case of emergency pressure drop in the brake actuator it is necessary to install special information systems in the cab of the car, which would inform the driver about the failure of the working brake system of the vehicle, as the efficiency of braking of the car can remain invariable, at an emergency condition of brake system of WV if limits of blocking of its wheels are not exceeded.

\section{Conclusions}

The proposed criterion $\left(K_{r}\right)$ for changing the cross-sections of chokes in electropneumatic pressure modulators, which provide adaptive inlet or outlet of air from the corresponding brake chambers of the drive, during the simulation of the system brake actuator.

It is established that due to the potential possibilities of realization of the coupling between the tires of automobile wheels and the road surface, the pressure in the electropneumatic brake drive, with its adaptive regulation, can be increased by no more than $0.04 \mathrm{MPa}$.

It is established that during the organization of the electropneumatic brake drive which provides at simultaneous growth of the adhesion realized on one axes of $\mathrm{WV}$ reduction of the adhesion realized on others axes, pressure in the drive can be increased by size no more than $0,025 \mathrm{MPa}$.

\section{References}

1. Ahmetshin A. M. (2003) Adaptivnaya antiblokirovochnaya tormoznaya sistema kolesnyih mashin. [Adaptive antiblock braking system for wheeled vehicles]: avtoref. dis. ... doktor teh. nauk : Moskva,. 36 s. [in Russian].

2. Antonov V.N., Prishvin A.M., Terehov V.A., Yanchevskiy A.E., (1984) Adaptivnyie sistemyi avtomaticheskogo upravleniya [Adaptive automatic control systems]: Leningrad.. 204 s. [in Russian].

3. Gromyiko V.D., (1974) Sankovskiy E. A., Samonastraivayuschiesya sistemyi s modelyu. [Self-adjusting systems with a model] Energiya. Moskva,. 80 s. [in Russian].

4. Turenko A.N., (2010) Adaptivnoe tormoznoe upravlenie kolesnyih mashin. [Adaptive braking control of wheeled vehicles] Zhurnal avtomobilnyih inzhenerov. Moskva. Vyip. 5(64). S. 18-21. [in Russian].

5. Turenko A.N., Shuklinov S. N., Mihalevich N. G., (2011) Elektropnevmaticheskiy privod tormozov s adaptivnyim upravleniem. [Electropneumatic brake actuator with adaptive control.] VolgGTU. Ser. «Nazemnyie transportnyie sredstva» Volgograd. Vyip. 4. S. 51-53. [in Russian].

6. Turenko A. N., Shuklinov S. N., Mihalevich N. G., (2012) Modelirovanie dinamiki kolesnoy mashinyi s adaptivnyim elektropnevmaticheskim privodom tormozov. [Simulation of the dynamics of a wheeled vehicle with an adaptive electropneumatic brake drive.] Vestnik Harkovskogo natsionalnogo avtomobilno-dorozhnogo universiteta. Harkov, Vyip. 56. S. 66-74. [in Russian].

7. Shuklinov S. N., (2014) Analiz vliyaniya konstruktivnyih parametrov avtomobilya i parametrov dvizheniya na oblast ustoychivosti adaptivnoy sistemyi tormozheniya. [Analysis of the influence of the design parameters of the vehicle and the parameters of movement on the stability area of the adaptive braking system] Vestnik Nats. teh. un-ta HPI. Harkov, Vyip 10.S. 40-47. [in Russian].

8. Turenko A. N., Shuklinov S. N., Verbitskiy V.I., (2012) Zamedlenie kolesnoy mashinyi kak parametr otsenki sostoyaniya sistemyi adaptivnogo tormoznogo upravleniya. 
Avtomobilnyiy transport Harkov. Vyip 31. S. 7-12. [in Russian].

9. Turenko A. B., Bogomolov V.A., Leontev D.N., (2016). Sposob opredeleniya zamedleniya mnogoosnogo avtomobilya na osnove realizuemyih stsepleniy ego koles i raspolozheniya koordinatyi tsentra mass. [A method for determining the deceleration of a multi-axle vehicle based on the realized adhesions of its wheels and the location of the center of mass coordinate]. Vestnik Harkovskogo natsionalnogo avtomobilno-dorozhnogo universiteta. Harkov, 75, 13-17. [in Ukrainian].

10. Bogomolov V.O., Klimenko V.I., Don E.Yu., TImonIn V.O., Verbitskiy V.I. (2019) Osoblivosti viboru ratsionalnih shem komponuvannya galmivnogo privodu pri zabezpechenni visokoyi efektivnosti galmuvannya bagatovisnogo transportnogo zasobu. [Features of the choice of rational schems for assembling a galvanized drive with a high efficiency of galvanizing a large transport system] Tehnichniy servis agropromislovogo lisovogo ta transportnogo kompleksiv. Harkiv, 17, 62-73. [in Ukrainian].

11. Leontev D.N. (2013) Modelirovanie perehodnyih protsessov $\mathrm{V}$ pnevmaticheskom tormoznom privode avtomobilya, kotoryiy oborudovan sistemoy avtomaticheskogo regulirovaniya tormoznogo usiliya [Simulation of transient processes in a pneumatic brake drive of a vehicle, which is equipped with an automatic brake force control system]. Visnik SevNTU. Ser.: Mashinopriladobuduvannya ta transport. Sevastopol, 142, 88-91. [in Russian].

12. Leontev D.N., (2013) Vliyanie algoritmov rabotyi avtomaticheskih sistem na effektivnost tormozheniya transportnogo sredstva. [Influence of algorithms of operation of automatic systems on the efficiency of braking of vehicles.] Visnik HarkIvskogo natsIonalnogo avtomobIlnodorozhnogo unIversitetu. Harkov, 61-62, 158-161. [in Russian].

13. Aksenov P.V. Mnogoosnyie avtomobili. [Multiaxle vehicles] Moskva, 1989. $280 \mathrm{~s}$ [in Russian].

14. Levin, M.A., Fufaev, N.A. (1989) Teoriya kacheniya deformiruemogo kolesa. [The theory of rolling deformed wheels]. Uchebnoe posobie. [in Russian].

15. Knoroz V.I. Klennikov E.V., Petrov I.P., Sheluhin A.S., Yrev U.M. (1976) Rabota avtomobilnoy shinu [vehicle tire operation] Uchebnoe posobie. [in Russian].

16. Klimenko V.I., Shuklinov S.N., Leontiev D.N., (2020) Analiz metodov opredeleniya roeficienta soprotivleniya kacheniu koles avtomobila [Analysis of methods for determining the coefficient of rolling resistance of vehicle wheels] Avtomobilnyiy transport, Harkov. 33 - 39 [In Russian].

17. Wong J.Y. (1982) Teoriya nazemnyih transportnyih sredstv [Theory of ground vehicles] Uchebnoe posobie [In Russian].
18. Fominyh A.B., Jeglov L.F., (2015) Harakteristiki shirokoprofilnoy avtomobilnoy shinyi na krupnyih nerovnostyah. [Wide - section Tire Features on Large Bumps] Sciense and Education of the Bauman. Moscow, 11, 1-11 [In Russian].

19. Mark Denny (2005) The dynamics of antilock brake systems. European Journal of Physics. 6. 1007-1016.

20. Leontiev D.N., Michalevich N.G., Frolov A.A., (2018) Vpliv vertikalnogo navantazhennya na galmIvnu silu ta koefitsient zcheplennya shini avtomobIlnogo kolesa. [Influence of Vertical load on Braking force tire adhesion coefficient of vehicle wheel]. Theory and Practice of Forensic Science and Criminalistics. Harkov, 18, 383-392.

21. Burckhardt M. (1979) Erfahrungen bei der Konzeption und Entwicklung des MercedesBenz, Bosch Anti-Blockier-Systems Automobiltechnische Zeitschrift. 5. 201-208.

22. Turenko A. N., Mikhalyevych N. G., Leontiev D. N. (2015) Realizatsiya intellektualnyih funktsiy $\mathrm{v}$ elektronno pnevmatichnom tormoznom upravlenii transportnyih sredstv. [Implementation of Intelligence Functions in Electronic-pneumatic Brake Control of Vehicles]. Monografiya [in Russian].

23. Gozhaev Z.A., Goncharenko S.V., Vleev D.H. (2015) Raschetno-eksperementalnaya otsenka tehnicheskih harakteristik shin gruzovyih avtomobiley. [Computational and experimental evaluation of the technical characteristics of truck tires]. Selskohozyaystvennyie mashinyi $i$ tehnologii, Moscow, 5, 14-19. [in Russian].

24. Pauwelssen J., Dalhuijsen W., Merts M. (2007) Tyre dynamics, tyre as a vehicle component Part. Arnhem.

25. Kraynik L.V., Dufanets I.G. (2008) Obgruntuvannya ta otsinka efektivnosti shemi galmovogo privodu trivisnogo monoblochnogo avtobusa. [Substantiation and evaluation of the efficiency of the brake scheme of a three-axle monoblock bus] Avtomobilniy transport, Harkiv, 42, 17-19.[in Ukrainian]

26. Kraynik L.V., Dufanets I.G. dinamika i parametrichna optimizatsiya galmovogo privodu trivisnogo avtobusa $\mathrm{z}$ monoblochnim kuzovom. [Dynamics and parametric optimization of the brake drive of a three-axle bus with a monoblock body.] visti avtomobilno-dorozhnogo institutu. Harkiv, 2009, 2(9), 33-36

27. Leontiev D., Klimenko V., Mykhalevych M., Don Y., Frolov A. (2020) Simulation of Working Process of the Electronic Brake System of the Heavy Vehicle. In: Palagin A., Anisimov A., Morozov A., Shkarlet S. (eds) Mathematical Modeling and Simulation of Systems. MODS 2019. Advances in Intelligent Systems and Computing, vol 1019. Springer, Cham. https://doi.org/10.1007/978-3-030-25741-5_6 


\section{Література}

1. Ахметшин А. М. Адаптивная антиблокировочная тормозная система колесных машин: автореф. дис. ... д-р техн. наук: Москва, 2003. $36 \mathrm{c}$.

2. Антонов В.Н., Пришвин А.М., Терехов В.А., Янчевский А.Э., Адаптивные системы автоматического управления: Ленинград, 1984. 204 с.

3. Громыко В.Д., Санковский Е. А., Самонастраивающиеся системы с моделью. Энергия. Москва, 1974. 80 с.

4. Туренко А.Н., Адаптивное тормозное управление колесных машин. Журнал автомобильных инженеров. Москва, 2010. Вып. 5 (64). C. 18-21.

5. Туренко А.Н., Шуклинов С. Н., Михалевич Н. Г. Электропневматический привод тормозов с адаптивным управлением. ВолгГТУ. Сер. «Наземные транспортные средства». Волгоград, 2011. Вып. 4. С. 51-53.

6. Туренко А. Н., Шуклинов С. Н., Михалевич Н. Г. Моделирование динамики колесной машины с адаптивным электропневматическим приводом тормозов. Вестник Харьковского нациионального автомобильно-дорожного универсиmета. Харьков, 2012. Вып. 56. С. 66-74.

7. Шуклинов С. Н., Анализ влияния конструктивных параметров автомобиля и параметров движения на область устойчивости адаптивной системы торможения. Вестник Нац. тех. ун-та ХПИ. Харьков, 2014. Вып. 10. C. $40-47$.

8. Туренко А. Н., Шуклинов С. Н., Вербитский В.И., Замедление колесной машины как параметр оценки состояния системы адаптивного тормозного управления. Автомобильный транспорт. Харьков, 2012. Вып. 31. С. 7-12.

9. Туренко А. Б., Богомолов В. А., Леонтьев Д. Н. Способ определения замедления многоосного автомобиля на основе реализуемых сцеплений его колес и расположения координаты центра масс. Вестник Харьковского национального автомобильно-дорожного университета. Харьков, 2016. Вып. 75. С. 13-17.

10. Богомолов В.О., Клименко В.І., Дон С.Ю., Тімонін В.О., Вербицький В.I. Особливості вибору раціональних схем компонування гальмівного приводу при забезпеченні високої ефективності гальмування багатовісного транспортного засобу. Технічний сервіс агропромислового лісового та транспортного комплексів. Харків, 2019. Вип. 17. С. 62-73

11. Леонтьев Д.Н. Моделирование переходных процессов в пневматическом тормозном приводе автомобиля, который оборудован системой автоматического регулирования тормозного усилия. Вісник СевНТУ. Сер.: Машиноприладобудування та транспорт. Севастополь, 2013. Вып. 142. С. 88-91.

12. Крайник Л.В., Дуфанець І.Г. Обгрунтування та оцінка ефективності схеми гальмового приводу тривісного моноблочного автобуса. Автомобільний транспорт. Харків, 2008. Вип. 42. С 17-19.

13. Крайник Л.В., Дуфанець І.Г. Динаміка і параметрична оптимізація гальмового приводу тривісного автобуса $з$ моноблочним кузовом. Вісник Харківського автомобільнодорожнього інституту. Харків, 2009. Вип. 2(9). С 33-36.

14. Леонтьев Д.Н., Влияние алгоритмов работы автоматических систем на эффективность торможения транспортного средства. Вісник Харківського національного автомобільнодорожнього університету. Харків, 2013. Вип. 61-62. С. 158-161.

15. Аксенов П.В. Многоосные автомобили. Москва, 1989. 280 с.

16. Левин М.А., Фуфаев Н.А. Теория качения деформируемого колеса. Москва, 1989. 272 с.

17. Кнороз В. И., Кленников Е. В., Петров И. П., Шелухин А. С., Юрьев Ю. М. Работа автомобильной шины. Москва, 1976. 238 с.

18. Клименко В. И., Шуклинов С. Н., Леонтьев Д. Н. Анализ методов определения коэффициента сопротивления качению колес автомобиля. Автомобильный транспорт. Харьков, 2020, Вып. 46. С. 33-39.

19. Вонг. Дж. Теория наземных транспортных средств. Москва, 1982. 284 с.

20. Фоминых А. Б., Жеглов Л. Ф. Характеристики широкопрофильной автомобильной шины на крупных неровностях. Наука и образование МГТУ им. Н.Э. Баумана. Москва, 2015. Вып. 11. C. $1-11$.

21. Mark Denny The dynamics of antilock brake systems. European Journal of Physics. 2005. № 6. P. 1007-1016.

22. Burckhardt M. Erfahrungen bei der Konzeption und Entwicklung des Mercedes-Benz, Bosch Anti-Blockier-Systems Automobiltechnische Zeitschrift. 1979. 5. Р. 201-208.

23. Леонтьєв Д. М., Михалевич М. Г., Фролов А. А. Вплив вертикального навантаження на гальмівну силу та коефіцієнт зчеплення шини автомобільного колеса. Теорія та практика судової експертизи і криміналістики. Харків, 2018, Вип. 18. С. 383 - 392.

24. Богомолов В. А., Рижих Л. А., Леонтьев Д. Н. , Красюк О. М. , Михалевич Н. Г. Реализация интеллектуальных функций в электронно-пневматичном тормозном управлении транспортных средств. Харьков, 2015. $450 \mathrm{c}$.

25. Гожаев 3.А., Гончаренко С.В., Влеев Д.Х. Расчетно-эксперементальная оценка технических характеристик шин грузовых автомобилей. Сельскохозяйственные машины и технологии, Москва, 2015, С. 14-19.

26. Pauwelssen J., Dalhuijsen W., Merts M., Tyre dynamics, tyre as a vehicle component Part. Arnhem, 2007, 50 p. 
27. Leontiev D., Klimenko V., Mykhalevych M., Don Y., Frolov A. (2020) Simulation of Working Process of the Electronic Brake System of the Heavy Vehicle. In: Palagin A., Anisimov A., Morozov A., Shkarlet S. (eds) Mathematical Modeling and Simulation of Systems. MODS 2019. Advances in Intelligent Systems and Computing, vol 1019. Springer, Cham. https://doi.org/10.1007/978-3-030-25741-5_6

Bogomolov Viktor ${ }^{1}$, professor, Doct of Technical Sciences, Associate Professor of the Departament of Automobiles named after A.B. Gredeskul, bogomolov.viktor@gmail.com,

тел. +380509027600,orcid: 0000-0001-6871-8244.

Klimenko Valeriy ${ }^{1}$, professor, Doct of Technical Sciences, Associate Professor of the Departament of Automobiles named after A.B. Gredeskul, valeriy.klimenko@gmail.com,

Tel. +38050-845-65-29, orcid:0000-0002-7399-0397. Leontiev Dmytro ${ }^{1}$, Candidate of Technical Sciences, Associate Professor of the Departament of Automobiles named after A.B. Gredeskul, dima.a3alij@gmail.com, Tel.+38 095-903-68-88, orcid: 0000-0003-4255-6317.

Kuripka Oleksandr ${ }^{1}$, PhD., student,

Tel.: +38 050-845-65-29,

kuripkas199721@gmail.com,

orcid: 0000-0002-0550-7201.

Frolov Andrii ${ }^{1}$, PhD., student, Tel.:+380988262198, andrey5120@mail.ru, orcid: 0000-0002-3868-4511.

Don Yevhen ${ }^{1}$, Candidate of Technical Sciences, Associate Professor of the Departament of Automobiles named after A.B. Gredeskul,

Tel.: +38 067-729-98-20, Evgenyj82@ gmail.com, orcid: 0000-0002-1508-8397.

${ }^{1}$ Kharkov National Automobile and Highway University, 25, Yaroslava Mudrogo str., Kharkiv, 61002, Ukraine.

Особливості адаптивного управління гальмом запасної гальмової системи багатовісного автомобіля

Анотація. Проблема. Несправність робочої гальмової системи колісного транспортного засобу (КТЗ) суттєво впливає на безпеку дорожнього руху, особливо під час експлуатаиії багатовісних транспортних засобів із великими масами. Одним із шляхів підвищення рівня безпеки дорожнього руху багатовісних транспортних засобів під час їх гальмування із застосуванням запасної (аварійної) гальмівної системи $є$ впровадження автоматизованих адаптивних гальмівних систем у конструкиію гальмівного приводу транспортних засобів. Визначення меж використання системи адаптивного гальмування на транспортних засобах з багатьма осями в науково-технічній літературі майже не розкривається, тому питання використання такої системи на транспортних засобах з великою кількістю осей вимагає додаткових досліджень. Мета. Метою даної роботи є розробка імітаційної моделі адаптив- ного керування прочесом гальмування багатовісного автомобіля з використанням запасної (аварійної) гальмівної системи з урахуванням моделювання динаміки приводу та мінливості властивостей зчеплення між шиною колеса автомобіля та поверхнею дорожнього покриття. Методологія. Для досягнення иієї мети необхідно розробити імітаційну модель гальмівного привода в адаптивному режимі, реалізувати модель взаємодії шини з дорожнім покриттям, реалізувати модель динаміки гальмування багатовісного автомобіля у випадку несправності його робочої гальмівної системи. Оригінальність. Запропонований ключовий критерій $\left(K_{r}\right)$ для зміни перерізу дросельної заслінки в електропневматичних модуляторах тиску, які забезпечують адаптивний впуск або випуск повітря з відповідних гальмівних камер привода, під час моделювання, дозволив змоделювати роботу контурів привода в адаптивному режимі. Встановлено, щзо залежно від потенційних можливостей реалізації зчеплення між шинами автомобільних коліс $i$ дорожнім покриттям тиск в електропневматичному гальмівному приводі при його адаптивному регулюванні може бути збільшений не більше ніж на 0,04 МПа.

Ключові слова: керування гальмами, багатовісний транспортний засіб, адаптивне керування, гальмування, запасна (аварійна) гальмівна система, екстрене гальмування, реалізоване зчеплення.

Богомолов Віктор Олександрович ${ }^{1}$, д.т.н., проф., каф. автомобілів ім. А.Б. Гредескула, bоgomolov.viktor@gmail.com,

тел. +38 050-902-76-00,

orcid: 0000-0001-6871-8244

Клименко Валерій Іванович ${ }^{1}$, д.т.н., проф., каф. автомобілів ім. А.Б. Гредескула,

valeriy.klimenko@gmail.com,

тел. +38 050-845-65-29 orcid: 0000-0002-7399-0397 Леонтьєв Дмитро Миколайович ${ }^{1}$, к.т.н., доц. каф. автомобілів ім. А.Б. Гредескула, dima.a3alij@gmail.com, тел. +38 095-903-68-88, orcid: 0000-0003-4255-6317

Куріпка Олександр Володимирович ${ }^{1}$, аспірант каф. автомобілів ім. А.Б. Гредескула,

kuripkas199721@gmail.com,

тел. +38 050-845-65-29,

orcid: 0000-0002-0550-7201

Фролов Андрій Анатолійович ${ }^{\mathbf{1}}$, аспірант каф. автомобілів ім. А.Б. Гредескула,

andrey5120@mail.ru, тел. +38 098-826-21-98, orcid: 0000-0002-3868-4511

Дон Євгеній Юрійович ${ }^{1}$, к.Т.Н., доц. каф. автомобілів ім. А.Б. Гредескула,

тел.: +38 067-729-98-20, Evgenyj82@gmail.com, orcid: 0000-0002-1508-8397.

${ }^{1}$ Харківський національний автомобільнодорожній університет, 61002, Україна, м. Харків, вул. Ярослава Мудрого, 25. 